\title{
MENGEMBANGKAN KEMAMPUAN KOGNITIF ANAK USIA DINI MELALUI PERMAINAN BALOK
}

\author{
Aisyah \\ Program Studi Pendidikan Guru Pendidikan Anak Usia Dini \\ Fakultas Pedagogik dan Psikologi Universitas PGRI Adi Buana Surabaya \\ Email : aisyah@unipasby.ac.id
}

\begin{abstract}
Cognitive as a thought process in the form of the ability to connect, assess and consider something. One of the cognitive abilities that children can develop is to recognize the concept of shape, color and size. Introducing the concept of shape, color, and size to children is important because color, shape and size are the most visible features in the world around us and can help children solve problems in life and adapt to their environment. There are 4 stages of child development, namely motor sensory, concrete preoperation, concrete operation, and formal operation. Through play activities that contain education, children's thinking powers are stimulated to stimulate emotional, social and physical development. Utilizing the surrounding environment as a means and source of learning by giving children the opportunity to explore experiences gained orally or with creative media. The use of blocks in early childhood education is intended to develop various abilities of children, in addition to providing opportunities for children to explore. Educational game tools (APE) for early childhood are always designed with in-depth thinking tailored to the child's age range. Game tools for children aged 4-5 years are made simpler and not too difficult compared to games for children aged 5-6 years which are more difficult to work on.
\end{abstract}

Keywords: Cognitive Ability, Early Childhood, Block Game

\section{PENDAHULUAN}

Kognitif sebagai suatu proses berpikir berupa kemampuan untuk menghubungkan, menilai dan mempertimbangkan sesuatu. Salah satu kemampuan kognitif yang dapat dikembangkan anak yaitu mengenal konsep bentuk, warna dan ukuran.Mengenalkan konsep bentuk, warna, dan ukuran pada anak penting dilakukan sebab warna, bentuk dan ukuran merupakan ciri yang paling terlihat dalam dunia sekeliling kita dan dapat membantu anak menyelesaikan masalah dalam kehidupan, serta beradaptasi dengan lingkungannya.

Permainan balok adalah salah satu permainan edukatif yang menggunakan potongan-potongan kayu berbentuk geometri yang dapat membuat anak mengekspresikan imajinasinya yang bersifat abstrak menjadi sesuatu yang konkrit dan mengembangkan kemampuan kognitif serta mendapatkan pemahaman konsep-konsep penting dalam pemecahan masalah, konsep matematika dan geometri.

Pengembangan kognitif yaitu satu pengembangan kemampuan dasar anak, yang bertujuan agar anak mampu meningkatkan kemampuan dan kreativitas sesuai dengan tahap perkembangan. Di samping itu, anak dapat mengembangkan pengetahuan yang sudah diketahui dengan pengetahuan yang baru diperolehnya. Dalam pelaksanaan pengembangan kognitif, kegiatan harus disesuaikan dengan kondisi lingkungan serta dikaitkan dengan tema. Bermain sambil belajar dapat mengembangkan aspek perkembangan anak usia dini. Aspek perkembangan yang dapat dikembangkan antara lain adalah Nilai agama moral, kognitif, fisik motorik,bahasa, sosial-emosional, dan seni. kemampuan kognitif anak khususnya dalam 
mengenal konsep bentuk, warna dan ukuran karena kegiatan di kelas masih berorientasi pada guru dan guru hanya memberikan kegiatan dan permainan yang monoton sehingga anak kurang tertarik dan cepat bosan. Sementara itu, penggunaan alat permainan edukatif kurang optimal dan keterbatasan media, guru hanya menggunakan lembar kerja siswa atau majalah untuk memberikan kegiatan didalam kelas sehingga anak cenderung pasif, kurang kreatif dan kurang mandiri.

\section{PEMBAHASAN}

Artikel ini membahas secara teoritis mengenai Kemampuan kognitif anak, tahapan perkembangan anak, manfaat kegiatan bermain yang mengandung edukasi, pemanfaatkan lingkungan sekitar sebagai sarana dan sumber belajar, penggunaan balok dalam pendidikan anak usia, dan alat permainan edukatif (APE) untuk anak usia dini.

Usia dini atau prasekolah merupakan usia yang efektif untuk mengembangkan berbagai potensi yang dimiliki anak-anak. 5 aspek perkembangan yang dimiliki anak meliputi Nilai Agama dan Moral, Fisik Motorik, Bahasa, Kognitif, dan Sosial Emosional harus dapat dikembangkan secara optimal. Upaya pengembangan ini dapat dilakukan dengan berbagai cara termasuk mengembangkan kemampuan kognitif anak agar dapat menyelesaikan masalah sendiri dalam kehidupannya nanti.

Tahap perkembangan menurut piaget terbagi menjadi 4 tingkat perkembangan kemampuan otak untuk berpikir mengembangkan pengetahuan kognitif, yaitu tahapan sensori motorik, pra-operasional kongkrit, operasional kongkrit, dan operasional formal. Pada tahap ini anak mengembangkan kemampuan untuk mengorganisasikan dan mengkoordinasikan serta mempersepsikan dengan gerakan-gerakan dan tindakan fisik yaitu: (a) Tahap sensorimotor sepanjang tahap ini mulai dari lahir hingga berusia dua tahun, bayi belajar tentang diri mereka sendiri dan dunia mereka melalui indea mereka yang sedang berkembang dan melalui aktivitas motor. (Diane, E. Papalia, sally wendkos Old and Ruth Duskin Fieldman, 2008:212). (b) Tahap praoperasional, pada tingkat ini anak telah menunjukkan aktivitas kognitif dalam menghadapi berbagai hal diluar dirinya. Aktivitas berfikirnya belum mempunyai sistem yang terorganisasikan. (c) Tahap operasional kongkrit,pada tahap ini anak sudah cukup matang untuk menggunakan pemikiran logika atau operasi, tetapi hanya untuk objek fisik yang ada saat ini.egosentrisnya berkurang dan kemampuan dalam tugas menjadi lebih baik.(d) tahap operasional formal, pada umur 12 tahun keatas, timbul periode operasi baru. Periode ini anak dapat menggunakan operasi-operasi konkritnya untuk membentuk operasi yang lebih kompleks. (Matt jarvis,2011:111).

Teori kontruktivisme menegaskan bahwa suatu proses aktif di mana anak membangun konsep atau gagasan baru berdasar pada pengetahuan yang telah mereka peroleh. Anak memilih dan mengubah bentuk informasi, membangun hipotesis, dan membuat keputusan, bersandar pada suatu struktur teori untuk melakukanya. Vygotsky, menjelaskan bahwa anak belajar dari benda nyata dan benda bergerak.

Kemampuan kognitif merupakan salah satu dari bidang pengembangan kemampuan dasar yang dipersiapkan oleh guru untuk meningkatkan kemampuan dan kreativitas anak sesuai dengan tahap perkembangannya. Pengembangan kemampuan kognitif bertujuan agar anak mampu mengolah perolehan belajarnya, menemukan bermacam-macam alternatif pemecahan masalah, pengembangan kemampuan logika matematika, pengetahuan ruang waktu, kemampuan memlilah dan mengelompokkan, dan persiapan pengembangan kemampuan berpikir teliti.

Melalui kegiatan bermain yang mengandung edukasi, daya pikir anak terangsang untuk merangsang perkembangan emosi, perkembangan sosial dan perkembngan fisik. Setiap anak mempunyai kemampuan dan ketertarikan bermain yang berbeda tergantung dari perkembangan anak. Dalam menentukan permainan edukatif, orang tua atau pendidik harus memilih permainan dan menyediakan media-media yang dapat mendukung perkembangan kepribadian anak, yang menyangkut fisik, intelektual, sosial, moral dan emosional anak.

Salah satu permainan menggunakan kemampuan kognitif yaitu bermain dengan balok, anak-anak mendapat kesempatan melatih kerja sama mata,tangan, serta kordinasi fisik. Balok unit adalah potongan-potongankayu yang memiliki bentuk beraneka ragam seperti segitiga, segiempat, persegi panjang dansetengah lingkaran. Bermain balok unit merupakan kegiatan main dengan cara menyusun potonganpotongan balok untuk membentuk suatu bentuk bangunan sesuai dengan imajinasi dan kemampuan anak dalam mendesain suatubentuk ruang dan bangunan. Permainan Balok merupakan potongan kayu yang memiliki 
berbagai bentuk.Umumnya berbentuk segi empat atau kubus. Pada perkembangannya, balok sebagai alat permainan tidak hanya dibuat dari kayu.Beragam bahan dipergunakan, seperti misalnya karton, busa, karet, dan sebagainya.

Beragam balok dapat dipergunakan sebagai alat permainan atau sarana belajar. Beberapa jenis balok yang dipergunakan sebagai alat permainan antara lain adalah balok unit, balok besar, balok berongga, balok pasak/lego, dan balok lainnya. (1) Balok unit merupakan balok yang memiliki bentuk dan ukuran standar (2) Balok besar merupakan balok berukuran besar macro play, dimana anak akan membangun rumah dengan skala sesuai dengan tinggi mereka. Tidak ada ukuran standar untuk balok besar ini, namun disyaratkan dibuat dari bahan yang ringan, misalnya karton. Balok besar dapat juga dibuat dengan memanfaatkan karton bekas bungkus, seperti misalnya bekas bungkus susu. Masukkan kertas koran kedalam bekas bungkus agar lebih kuat dan awet dipakai bermain. Karton-karton bekas tadi dapat dibungkus kertas berwarna agar menarik. (3) Balok berongga pada prinsipnya kegunaannya sama dengan balok besar, yaitu untuk bermain macro play. Bedanya hanya pada bahannya, dimana balok berongga dibuat dari kayu/papan. (4) Balok pasak/lego. Balok pasak merupakan balok yang setiap baloknya memiliki pasak pada bagian atas dan lobang pada bagian bawah. Bahan balok ini umumnya kayu atau plastik. Contoh terkenal dari balok pasak ini adalah lego. Balok pasak ini lebih disukai anakanak karena memberikan lebih banyak pilihan bentuk, yang tidak dapat dilakukan bila menggunakan jenis balok lainnya. (5) Balok lainnya. Jenis balok lainnya cukup banyak,seperti balok alphabet, dan sebagainya. Penggunaan balok dalam pendidikan anak usia dini dimaksudkan untuk mengembangkan berbagai kemampuan anak, di samping untuk memberikan kesempatan bagi anak bereksplorasi.

Manfaat permainan balok adalah mengembangkan konsep matematika dan geometri, mengembangkan keterampilan membedakan penglihatan. Dalam mengembangkan konsep matematika dan geometri, balok diciptakan dalam bentuk matematis maka anak yang memainkannya dilatih memiliki pengertian konkret dari konsepkonsep penting dalam berpikir logis, termasuk kemampuan menggunakan klasifikasi (misalnya meletakkan balok yang sama bentuknya, sama warnanya, dan yang sama ukurannya), serial (misalnya, mengurutkan dari yang paling pendek ke yang paling tinggi). Anak dapat belajar konsep matematika yaitu kemampuan mengembangkan konsep bentuk, warna dan ukuran dengan permainan balok, mengenal bentuk lingkaran, silindris, segiempat, segitiga, Membedakan warna-warna pada balok dan dapat membedakan ukuran balok yang bermacam-macam. Melalui permainan balok, anak akan belajar ukuran, bentuk, warna, jumlah, urutan, lokasi, panjang dan berat pada saat mereka membangun dan merapikan balok.

Dalam bermain anak memiliki nilai kesempatan untuk mengekspresikan sesuatu yang ia rasakan dan ia pikirkan. Anak mempraktikkan keterampilan dan mendapatkan kepuasan dalam bermain, yang berarti mengembangkan dirinya sendiri.Selanjutnya anak dapat mengembangkan otot kasar dan halus, meningkatkan penalaran, dan memahami keberadaan lingkungannya, membentuk daya imajinasi, daya fantasi, dan kreativitasnya.

Metode yang dapat digunakan dalam mengembangkan kognitif meliputi : pemberian tugas, demonstrasi, tanya jawab, mengucapkan sya'ir, percobaan, eksperimen, bercakap-cakap, bercerita dan praktik langsung. Dalam menggunakan metode seperti ini, guru dapat memilih salah satu atau gabungan dari beberapa metode yang sesuai dengan kemampuan, fasilitas kegiatan belajar mengajar yang disajikan, serta sesuai dengan bahan pengembangan dan kebutuhan, minat dan kemampuan serta lingkungan anak.

Dalam memberikan kegiatan pengembangan kognitif hendaknya mengacu kepada kompetensi yang hendak dicapai dan sedapat mungkin dikaitkan dengan tema yang sedang dibahas. Pelaksanaan kegiatan pengembangan kognitif dapat menggunakan bermacam-macam metode yang sesuai dengan kompetensi yang hendak dicapai.Memanfaatkan lingkungan sekitar sebagai sarana dan sumber belajar dengan memberi kesempatan anak untuk mengeksplorasi pengalaman yang didapat secara lisan atau dengan media kreatif, kegiatan yang diberikan hendaknya merupakan pengetahuan yang objektif dan sesuai dengan kenyataan.

Mengingat pentingnya masa ini, maka peran stimulasi berupa penyediaan lingkungan yang kondusif harus disiapkan oleh para pendidik, baik orang tua, guru, pengasuh ataupun orang dewasa lain yang ada disekitar anak, sehingga anak memiliki kesempatan untuk mengembangkan seluruh potensinya. Potensi yang dimaksud meliputi aspek moral dan nilai-nilai agama, sosial, emosional dan kemandirian, kemampuan berbahasa, kognitif, fisik/motorik, kreativitas dan 
seni. Pendidikan anak usia dini diberikan pada awal kehidupan anak untuk dapat berkembang secara optimal. Supaya tercapai seluruh aspek perkembangan pada anak usia dini dengan menggunakan prinsip belajar melalui bermain dalam metode pembelajaran-nya.Terkait dengan itu, orang tua dan guru perlu menyediakan lingkungan yang benar untuk membebaskan seluruh potensi kreatifnya. Di dalam pendidikan anak usia dini, orang tua dan guru bukanlah pengajar, melainkan sebagai motivator, fasilitator. Orang tua dan guru diharapkan memberikan stimulus pada anak, sehingga terjadi proses pembelajaran yang berpusat pada anak (student centered). Biarkan anak dengan bebas melakukan, memegang, menggambar, membentuk, ataupun membuat dengan caranya sendiri dan menguraikan pengalamannya sendiri. Bebaskan daya kreatif anak dengan membiarkan anak menuangkan imajinasinya. Ketika anak mengembangkan keterampilan kreatif, maka anak tersebut juga dapat menghasilkan ide-ide yang inovatif dan jalan keluar dalam menyelesaikan masalah serta meningkatkan kemampuan dalam mengingat sesuatu.

Lingkungan keluarga yang baik, sekurangkurangnya mempunyai tiga ciri, yaitu: Pertama, keluarga memberikan suasana emosional yang baik bagi anak-anaknya, seperti perasaan senang, aman, disayangi, dan dilindungi. Kedua, mengetahui dasar-dasar kependidikan, terutama berkenaan dengan kewajiban dan tanggung jawab orang tua terhadap pendidikan anak serta tujuan dari isi pendidikan yang diberikan kepadanya. Ketiga, bekerjasama dengan pusat pendidikan tempat orang tua mengamanatkan pendidikan anaknya.

Proses pembelajaran pada pendidikan anak usia dini menjadi permasalahan yang pelik di Indonesia beberapa tahun terakhir. Hal ini disebabkan karena pembelajaran yang dilaksanakan cenderung berorientasi akademik, pembelajaran yang lebih menekankan pada pencapaian kemampuan anak dalam membaca, menulis, dan berhitung (baca: calistung). Seharusnya, pembelajaran di jenjang pendidikan anak usia dini (0-6 tahun) lebih diarahkan untuk mengembangkan berbagai potensi yang terdapat dalam diri anak, seperti: fisik, kognisi, bahasa, dan sosio-emosional. Kecenderungan tersebut disebabakan antara lain karena pemahaman yang keliru terhadap konsep pembelajaran awal pada anak.

Pola asuh orang tua terhadap anak memiliki peran penting dalam upaya mengembangkan kreativitas anak. Pola asuh belajar adalah interaksi antara anak dan orang tua selama mengadakan kegiatan pengasuhan dalam mendidik anak. Gaya pengasuhan dalam mendidik anak diukur berdasarkan kategori positif dan negatif dengan tolak ukur kontrol orang tua, kejelasan komunikasi dan tuntutan orangtua menjadi matang.(Rini Harianti, 2016) Disamping pola asuh orang tua, gaya belajar anak juga mempengaruhi perkembangan kreativitas anak. semakin baik gaya belajar siswa maka semakin baik pula hasil belajarnya. Sebaliknya, semakin buruk gaya belajar siswa maka semakin rendah hasil belajarnya. (Tanamir, 2016) hasil belajar dalam penelitian ini terkait dengan kreativitas anak usia dini.

Kreativitas biasanya diartikan sebagai kemampuan untuk menciptakan suatu produk baru, baik yang benar-benar baru sama sekali, maupun merupakan modifikasi atau perubahan dengan menggabungkan hal-hal yang sudah ada. Jika konsep ini dikaitkan dengan kreativitas anak, anak yang bersangkutan mungkin menciptakan suatu karya yang benar-benar baru dan orisinil (asli ciptaan sendiri), atau dapat saja merupakan modifikasi dari berbagai cara belajar yang ada sehingga menghasilkan bentuk baru. Tumbuhnya kreativitas pada anak usia dini, memungkinkan terwujudnya ide perubahan dan upaya peningkatan secara terus menerus, dan sesuai dengan situasi dan kondisi lingkungan di mana sekolah berada. Disamping itu, tuntutan untuk meningkatkan kemampuan anak muncul dari dalam diri sendiri, tanpa menunggu ide ataupun perintah dari orang lain.

Penggunaan balok dalam pendidikan anak usia dini dimaksudkan untuk mengembangkan berbagai kemampuan anak, di samping untuk memberikan kesempatan bagi anak bereksplorasi. Permainan Balok termasuk Alat Permainan Edukatif (APE).APE adalah alat permainan yang sengaja di rancang secarakhusus untuk kepentingan pendidikan. Alat permainan edukatif (APE) untuk anak usia dini selalu di rancang dengan pemikiran yang mendalam disesuaikan dengan rentang usia anak. alat permainan untuk anak usia rentang 4-5 tahun di buat dengan lebih sederhana dan tidak terlalu sulit dibandingkan dengan alat permainan untuk anak usia rentang 5-6 tahun yang lebih sulit pengerjaannya.

\section{SIMPULAN DAN SARAN}

\subsection{Simpulan}

Berdasarkan uraian di atas dapat disimpulkan sebagai berikut (1) Kemampuan kognitif merupakan salah satu dari bidang 
pengembangan kemampuan dasar yang dipersiapkan oleh guru untuk meningkatkan kemampuan dan kreativitas anak sesuai dengan tahap perkembangannya. (2) terdapat 4 tahapan perkembangan anak yaitu sensori motorik, praoperasional kongkrit, operasional kongkrit, dan operasional formal. (3) Melalui kegiatan bermain yang mengandung edukasi, daya pikir anak terangsang untuk merangsang perkembangan emosi, perkembangan sosial dan perkembngan fisik. (4) Memanfaatkan lingkungan sekitar sebagai sarana dan sumber belajar dengan memberi kesempatan anak untuk mengeksplorasi pengalaman yang didapat secara lisan atau dengan media kreatif. (5) Penggunaan balok dalam pendidikan anak usia dini dimaksudkan untuk mengembangkan berbagai kemampuan anak, di samping untuk memberikan kesempatan bagi anak bereksplorasi.(6) Alat permainan edukatif (APE) untuk anak usia dini selalu di rancang dengan pemikiran yang mendalam disesuaikan dengan rentang usia anak. Alat permainan untuk anak usia rentang 4-5 tahun di buat dengan lebih sederhana dan tidak terlalu sulit dibandingkan dengan alat

permainan untuk anak usia rentang 5-6 tahun yang lebih sulit pengerjaannya.

\subsection{Saran}

Pendidik dan orangtua sebaiknya memahami perkembangan kognitif pada anak usia dini, sehingga mampu memlilih metode pembelajaran yang benar dan pola asuh yang tepat dalam proses belajarnya, sehingga anak usia dini dapat berkembang di sekolah dan berikan motivasi belajar dalam segala hal kegiatan yang mereka lakukan supaya anak dapat berkreasi dan mengembangkan kemampuan kognitif sesuai dengan pengalaman.

\section{REFERENSI}

Depertemen Pendidikan Nasional. (2007). Pengembangan Kognitif di Taman KanakKanak. Jakarta: Direktorat Pembinaan Taman Kanak.

Fauziddin, Muhammad. (2016). Penerapan Belajar Melalui Permainan Balok Unit untuk Meningkatkan Kreativitas Anak Usia Dini. Dalam Jurnal Manajemen Pendidikan Vol 1 No.3, 2016. Diunduh pada hari Rabu, tanggal 20 Desember 2017 Pukul 17.14 WIB.

Holis, Ade. (2016). Belajar Melalui Bermain untuk Pengembangan Kreativitas dan Kognitif anak usia dini. Di dalam Jurnal Manajemen Pendidikan. Vol 09 No01,2016. Diunduh pada hari Rabu, tanggal 20 Desember2017 Pukul 17.20 WIB

Ibda, Fatimah. (2015). Perkembangan kognitif teori Jean Piaget. Dalam Jurnal Manajemen Pendidikan. Vol 3 No-1, Januari-Juni 2015. Diunduh pada hari Selasa, tanggal 19 Desember 2017 Pukul 20.33 WIB

Widyastuti, Sari. 2015. Permainan balok berpengaruh terhadap kemampuan kognitif anak. Universitas Muhammadiyah Surakarta. Diunduh pada hari Senin, tanggal 18 Desember 2017 Pukul 16.45 WIB. 